\title{
MARKET ENTRY STRATEGIES OF PASSENGER CARMAKERS - THE CASE STUDY OF THE CZECH REPUBLIC
}

Machková, H., Collin, P.-M.

In 2014, the Czech automotive industry had a record-breaking year with 1278000 motor vehicles manufactured. This was a result of the investment of three major carmakers, who entered into the Czech Republic, because they believed in the industrial capacity of the country and its strategic location in Central Europe. The goal of this article is to analyze the different entry strategies into the Czech market and to compare the results of different strategic approaches for both foreign private investors and the recipient country. The main research method used in this article is a case study. In our case studies, we will analyze the cases of the Volkswagen group and its acquisition of the manufacturer Škoda, the greenfield investment of Hyundai, and the strategic alliance of the French car producer PSA with Japanese Toyota who had founded the TPCA joint venture in the Czech Republic. All three case studies show examples of good practices and prove that foreign direct investment (FDI) has the potential to generate employment, raise productivity, transfer skills and technology, enhance exports and contribute to the long-term economic development of the country.

Keywords: market entry strategies; car manufacturers; case study; Czech Republic JEL Classification: F60, M05

\section{Introduction}

Czech Republic has a unique position in Central and Eastern Europe, gifted with a long automotive tradition. Today, the country is highly integrated into the European automotive value chain and it can offer a qualified labor force, developed infrastructure and innovation capacity. The Czech automotive industry is a key sector of the Czech economy, which employs more than 150000 people (highest active population ratio in EU countries in direct automotive manufacturing employment) and accounts for more than $20 \%$ of exports (AutoSAP, 2015). The small Czech Republic with its 10.5 million inhabitants is the thirteenth largest global passenger car producer by volume. And per capita, in 2014, the Czech Republic was in $2^{\text {nd }}$ place after Slovakia, with a production of 118.4 cars per 1000 inhabitants.

The passenger car production is completely under the control of foreign capital. "A capital mode of entry to foreign markets is typical for financially strong companies that want to keep control over international activities. Ownership requires the greatest commitment of capital, know-how and managerial effort and offers the fullest means of presence in a foreign market" (Machková et al., 2010, p. 75). Car production is highly capital intensive and passenger car production requires significant investments, R\&D included, because innovation is now-a-days driving competition. This is why car manufacturing is one of the most concentrated industries in the world. 


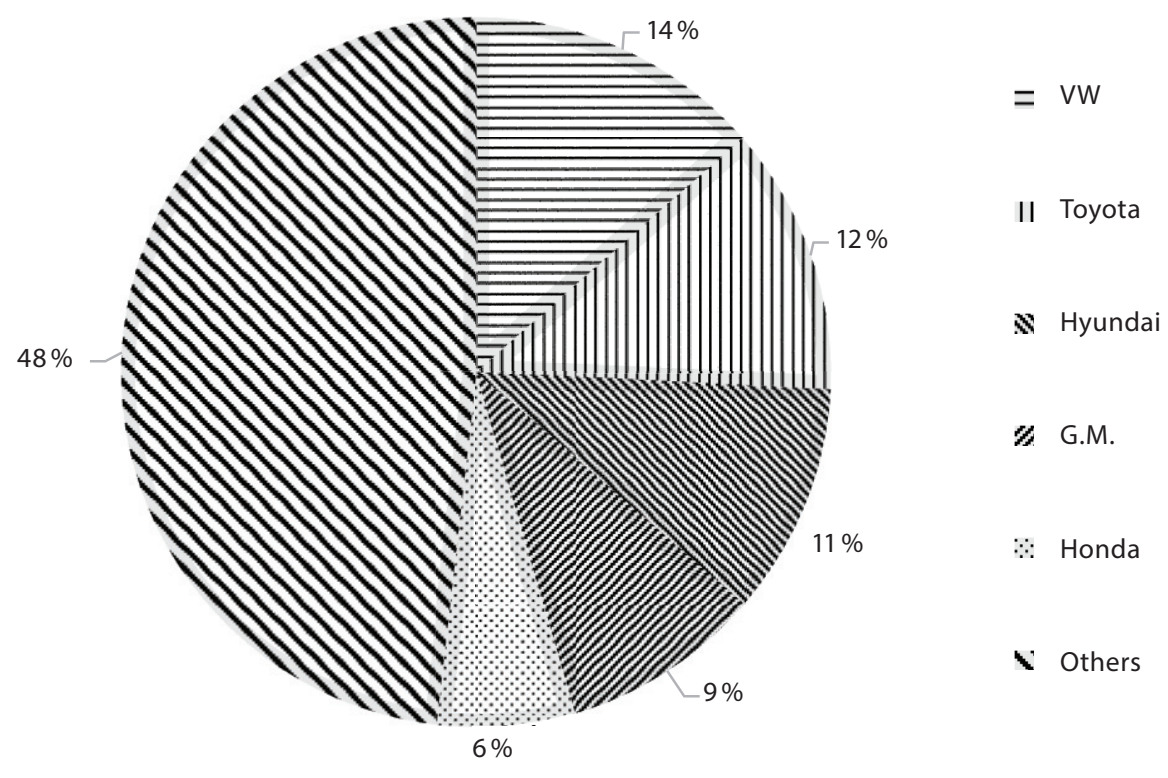

Source: OICA (2014).

The top five companies have a significant share $(52 \%)$ of the global automotive market and the TOP 3 manufacturers, e.g. VW, Toyota (together with No. 10 PSA Peugeot Citroën) and Hyundai decided to invest in the Czech Republic. The country is the leader for gathering automotive industry investments in the CEE region.

The goal of this article is to analyze the different entry strategies into the Czech market and to compare results of different strategic approaches for both the foreign private investors and the recipient country.

The article is organized in the following manner. First, we provide a review of the relevant literature. Then we present three case studies of market entry strategies in the Czech Republic: Volkswagen, Hyundai and TCPA. Finally, we discuss the differences and provide concluding remarks.

\section{Literature Review}

The decision regarding how an organization will enter a new international market is one of the key decisions made in international business strategy. The company may choose a number of modes or methods regarding how to enter. Modes of international market entry can be divided into three main groups: (1) exporting, (2) non-equity based cooperations (such as licensing), and (3) foreign capital investments (Canabal and White, 2008). Even though in the automotive industry all three groups are used, in this article, we will focus on foreign capital investment typical for manufacturing.

Under foreign capital investment, we can understand foreign direct investment (FDI) or portfolio investment. "FDI is a category of investment that reflects the objective of 
establishing a lasting interest by a resident enterprise in one economy (direct investor) in an enterprise (direct investment enterprise) that is resident in an economy other than that of the direct investor. The lasting interest implies the existence of a long-term relationship between the direct investor and the direct investment enterprise and a significant degree of influence on the management of the enterprise. The direct or indirect ownership of $10 \%$ or more of the voting power of an enterprise resident in one economy by an investor resident in another economy is evidence of such a relationship" (OECD, 2015).

Many research articles and books investigate the impact of FDI on the economic development of CEE countries, but only a few pay attention to sectorial issues. Korniecki and Rhoades (2007) examined the role of FDI in facilitating advancing the globalization process in CEE economies, and described how FDI stimulates economic growth. Guidote (2008) stated that in the case of the Czech Republic, the role of FDI in the transformation of its car industry has been significant. "If one were to analyze the Czech car industry alone, it is faring quite well compared to other car industries across the globe. Skoda itself is in a better position than VW in Germany, for example. But it must work to maintain this favorable position by capitalizing on its competitive advantages. While it may no longer be attracting investment on the basis of its previous appeal, i.e., cheap labor, it has developed a highly competitive R\&D position globally. This highly significant competitive edge must be maintained and further strengthened."

Lattore and Gomez-Plana (2011) offered a computable general equilibrium methodology to analyze the involvement of multinationals in the motor vehicles sector in the post-communist Czech Republic. Lattore (2012) analyzes the rapid entry of multinationals into the motor vehicles sector of the Czech Republic that occurred before the recent crisis, and assesses the impact on GDP and welfare resulting from the process of industry restructuring at the microeconomic level.

Manufacturing is the largest recipient of foreign direct investment in the Czech Republic, accounting for about a third of inflows. Together, the foreign carmakers have directly invested more than $€ 14$ billion in the country and created billions of euros more in downstream opportunities. The main modes of FDIs in the passenger carmaker industry are, in general, mergers and acquisitions (M\&As), greenfield investments, joint ventures and strategic alliances.

Acquisition (takeover) means acquiring control of a corporation by stock purchase or exchange. Different from a merger, an acquisition does not necessarily entail amalgamation or consolidation of the firms. An acquisition, even when there is complete change in control, may lead the firms involved to continue to operate as separate entities. A merger is an amalgamation or joining of two or more firms into an existing firm or forming of a new firm. By merging, firms can increase their size and expand into existing or new economic activities and markets. There are a variety of motives for mergers and acquisitions: to increase productivity, cost efficiency, to acquire market share, to penetrate local distribution channels, to diversify brand portfolio, to expand into different geographic markets, to obtain new know-how or access to innovations (Tyll, 2015).

A greenfield investment is establishment of a new operating form by constructing new facilities from the ground up. In addition to building new facilities, most parent companies also create new jobs in the foreign country by hiring new employees.

A joint venture involves shareholding in a business entity. A joint venture often combines the market knowledge and skills of the local firm with the production and 
technological capabilities of the company willing to enter the market. Companies that lack sufficient capital resources might seek partners to jointly finance business activities. Two types of joint ventures can be distinguished. Equity joint ventures are based on an agreement, possessing the legal characteristics of a partnership, between two or more parties that join forces to achieve some specific goal. Under non-equity joint ventures (also known as cooperative agreements or contractual joint ventures), the parties seek arrangements without capital investment, for example for technical assistance, joint research projects, services, etc.

"The disadvantage of joint venturing can be significant. The main disadvantage of this global expansion strategy is that the company incurs very significant costs associated with control and coordination issues that arise when working with a partner. Also a dynamic joint venture partner can evolve into a stronger competitor. In some instances, country-specific restrictions limit the share of capital help by foreign companies. Cross-cultural differences in managerial attitudes and behavior can present formidable challenges as well" (Keegan and Schlegelmilch, 2001, p. 296).

The principles of strategic alliances are similar to joint ventures, but the motivations of the creation are different. "Strategic alliance can be defined as "a form of cooperation, where (i) the partners remain independent even after entering the alliance, (ii) the partners share the benefits, risks as well as the control in the alliance and (iii) they provide technologies, products and other strategic resources for the partnership" (Keegan and Schlegelmilch, 2001, p. 309). In the case of joint venture, often a strong company cooperates with a smaller company or with a company from a developing country. The partners in a strategic alliance are always big companies, which together develop a joint long-term strategy to achieve market leadership by pursuing cost leadership, technology leadership, etc. The strategic alliance form of cooperation started in industries where research and technology requirements were so high that for an individual company it was hard to achieve adequate results alone. Examples of industries where this was the case include: telecommunications, IT, automotive and aerospace. Nowadays, strategic alliances are used any time it is the quickest and cheapest way to develop a global strategy for partnering firms possessing specific strengths.

\section{Capital Entry Strategies of Global Car Makers into the Czech Republic}

According to Yin (Yin, 2014) a case study investigates a contemporary phenomenon (the "case") in its real-world context. In this article, we will use three different cases to show the variety of choices when entering a foreign market with the same goal - manufacturing to export to other foreign markets. The attractiveness of the location for factories in the Czech Republic is supported by relatively cheap labor costs, educated, skilled and disciplined workforce, improving infrastructure, the geographical location connecting west and east and also by safety. According to Global Peace Index 2015, the Czech Republic is in the $10^{\text {th }}$ place in the world and the $1^{\text {st }}$ place among CEE countries. The result is influenced by the fact that Czech Republic is neighboring only with Schengen countries.

The location of three big manufacturing plants is the main reason for the robust supplier base facilitating supplies and logistics of manufacturing operations. Today, the Czech Republic has become a true "auto land". Except for one region, there is at least one automotive factory everywhere. 


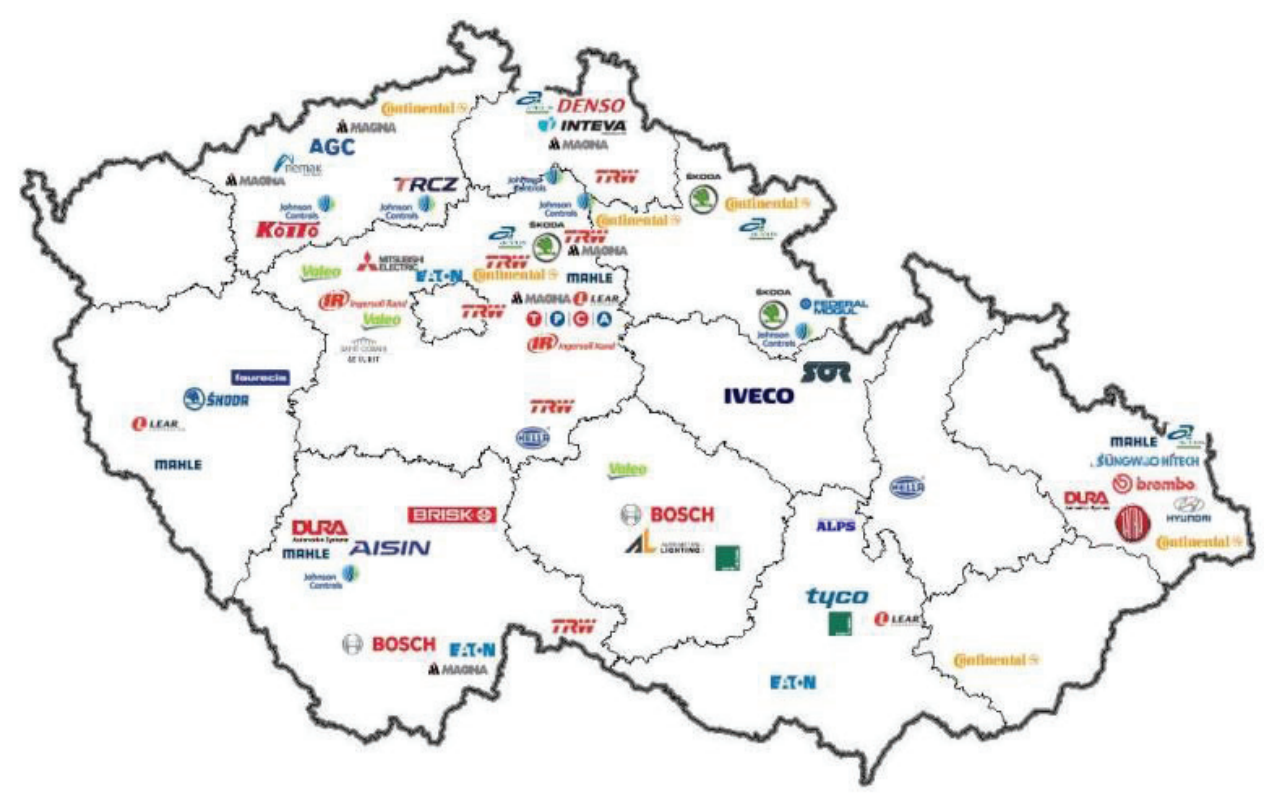

Source: Czechlnvest (2015).

The Czech plants are delivering products mainly to European markets. "The share of export on the domestic production of motor vehicles in the Czech Republic achieved 80\%, and the share of the consolidated export on the production of the automotive components reached even higher value, as it amounted to $89 \%$. Until now, about $80 \%$ of the production has been exported to EU member states" (Machková and Mohelský, 2012).

According to Škoda Auto's 2014 Annual Report (Škoda Auto, 2014), in 2014, the global automotive market continued to grow. As for the European market, there was a slight recovery in demand for new cars. Exceptions here were the markets in Ukraine and Russia, which were among the few European countries to show a significant drop in demand for passenger cars throughout almost the whole year, due to political and economic reasons. Positive developments were seen in Central and Western Europe. In Western Europe, the year-on-year increase in car sales was of 3.8\%, reaching a volume of approximately 84.1 million cars, of which about 73.4 million were passenger cars. The Central European market developed positively and exceeded expectations in 2014 with a year-on-year increase of $14.1 \%$. The Czech automobile market experienced significant growth compared with the previous year, with a total of 192314 vehicles sold, representing a year-on-year increase of $16.7 \%$. In mid-2015, the total number of registered cars surpassed 5 million, which was two times more than at the end of the communist time. Škoda has been the market leader "forever", today with more than $30 \%$ of the market share (Škoda Auto, 2014).

The Czech passenger car production had a record-breaking year in 2014 with 1246506 manufactured cars, of which Škoda Auto's production share was 59\%, Hyundai $25 \%$ and TPCA $16 \%$. The Czech Republic with only 10.5 million inhabitants is ranked $13^{\text {th }}$ among producers of passenger cars and the country is approaching production volumes of six times bigger than France $\left(12^{\text {th }}\right)$ or the UK $\left(11^{\text {th }}\right)$. 
Table 1 | Passengers cars - major producing countries

\begin{tabular}{|l|c|c|}
\hline Country & Production, units & Number of inhabitants \\
\hline China & 19919795 & 1364270000 \\
\hline Japan & 8277070 & 127131800 \\
\hline Germany & 5604026 & 80889954 \\
\hline USA & 4253098 & 318857056 \\
\hline South Korea & 4121116 & 50423055 \\
\hline India & 3158215 & 1267401849 \\
\hline Brazil & 2314789 & 202033670 \\
\hline Mexico & 1915709 & 123799215 \\
\hline Spain & 1898342 & 46404602 \\
\hline Russia & 1692505 & 143819569 \\
\hline UK & 1528148 & 64510376 \\
\hline France & 1499464 & 10510566 \\
\hline Czech Republic & 1246506 & \\
\hline
\end{tabular}

Source: OICA (2014)

Table 2 | Basic figures of car manufacturers in the Czech Republic (2014)

\begin{tabular}{|l|r|r|c|}
\hline & \multicolumn{1}{|c|}{ Škoda Auto } & \multicolumn{1}{c|}{ TPCA } & Hyundai Motors Czech \\
\hline Turnover & 299.3 bil. CZK & 39.3 bil. CZK & 92.3 bil. CZK \\
\hline Local car production & 735951 & 203105 & 303450 \\
\hline Number of factories & 3 & 1 & 1 \\
\hline Number of employees & 3400 CZK & 30600 CZK & 3400 \\
\hline Average wage in production & $\begin{array}{c}1 \text { 037 226 (incl. } \\
\text { Deliveries to customers }\end{array}$ & 209105 & 289642 \\
\hline Sales in Czech Republic & $\begin{array}{c}70 \text { 200 } \\
\text { production abroad) }\end{array}$ & 8505 & 13808 \\
\hline Brand portfolio & $\begin{array}{c}\text { Škoda Citigo } \\
\text { Škoda Fabia } \\
\text { Škoda Roomster } \\
\text { Škoda Rapid } \\
\text { Škoda Yeti } \\
\text { Škoda Octavia } \\
\text { Škoda Superb }\end{array}$ & $\begin{array}{c}\text { Peugeot 108 } \\
\text { Citroën 1 }\end{array}$ & $\begin{array}{c}\text { Tyota Aygo } \\
\text { Hyundai ix } 35 \\
\text { Hyundai ix20 }\end{array}$ \\
\hline
\end{tabular}

Source: Škoda Auto (2014). 
The share of exports to GDP is higher than $80 \%$ and the Czech economy strongly relies on manufacturing exports. The passenger car is the flagship export products and its share in total exports exceeds $20 \%$. Even though the Czech production is price competitive, none of the three manufacturers uses the positioning of low-cost cars. In 2014, all three manufacturers announced good results and were optimistic for future growth.

\subsection{Volkswagen Gave a New Breath of Life to the Škoda Brand by Acquisition}

Škoda with its 120 years history is one of the oldest car brands in the world. Following the political changes in 1989, the new Czech government decided to privatize the company and was seeking a strong foreign investor. The final choice was between the French car maker Renault and the German group Volkswagen. While Renault offered manufacturing of its own model Renault 18, VW understood much better the Czechoslovakian culture and its engineering and industrial tradition. VW decided to bring a new breath of life to the country's national brand Škoda and to keep and develop the R\&D activities in Mladá Boleslav. Both promises were kept - Škoda is one of the most successful VW group brands (since 1991, when Škoda became the fourth brand besides VW, Audi and Seat, Škoda created a portfolio of eight competitive car models on the global level), and more than 1650 employees are involved in development of new models in the country. An example of successful "glocalization" in car manufacturing was born in Central Europe.

Škoda Auto has not only three production plants in the Czech Republic, but Škoda brand cars are manufactured also in China, Russia, India, Slovakia, the Ukraine and Kazakhstan. In 2014, more than 1 million Škoda branded cars were manufactured in Europe and Asia and sold worldwide.

Figure 3 | Portfolio models manufactured worldwide

\begin{tabular}{|c|c|c|c|c|c|c|c|c|}
\hline & & 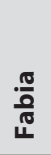 & $\frac{\text { 응 }}{\frac{0}{\delta}}$ & 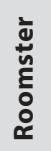 & 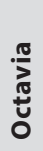 & $\begin{array}{l}\bar{E} \\
\stackrel{ \pm}{\nu}\end{array}$ & 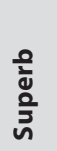 & 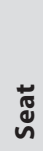 \\
\hline Mladá Boleslav (Czech Republic) & & $\mathrm{X}$ & $X$ & & $\mathrm{X}$ & & & $\mathrm{X}$ \\
\hline Kvasiny (Czech Republic) & & & & $\mathrm{X}$ & & $x$ & $\mathrm{X}$ & \\
\hline Bratislava (Slovakia) & $\mathrm{X}$ & & & & & & & \\
\hline Kaluga (Russia) & & $\mathrm{X}$ & $\mathrm{X}$ & & & & & \\
\hline Nizhny Novgorod (Russia) & & & & $x$ & & $\mathrm{X}$ & & \\
\hline Aurangabad (India) & & & & $\mathrm{X}$ & & $x$ & $x$ & \\
\hline Pune (India) & & & $\mathrm{X}$ & & & & & \\
\hline Anting (China) & & $\mathrm{X}$ & & $\mathrm{X}$ & & $X$ & & \\
\hline Yizheng (China) & & & $\mathrm{X}$ & & & & & \\
\hline Ningbo (China) & & & & $\mathrm{X}$ & & & $\mathrm{X}$ & \\
\hline
\end{tabular}

Source: Adapted from Škoda Auto (2014, p. 20). 
“We continued our model initiative and, as a first in our company's almost 120-year history, we produced over one million vehicles and delivered them to customers worldwide - a new milestone for our brand. So 23 years after joining the Volkswagen Group, ŠKODA has secured a lasting spot in the volume segments of the international car markets. Sales and operating income reached a new record high as well," wrote the CEO W. Vahland in his foreword of the 2014 Annual Report. His vision of clever engineering with a human touch expressed by the "Simply Clever" slogan is a true success story.

Figure 4 | "Simply Clever" - the Company's mission

\begin{tabular}{|c|c|l|}
\hline & Profitability and financial strength & \\
\hline $\begin{array}{r}\text { Sales > } 1.5 \text { million vehicles, } \\
\text { focus on EU and RIC-markets }\end{array}$ & ŠKODA & $\begin{array}{l}\text { Strategic "spearhead" focused } \\
\text { on price/value, practicality and } \\
\text { spaciousness }\end{array}$ \\
\hline & Top-employer with global talent pool & \\
\hline
\end{tabular}

Source: Adopted from Škoda Auto (2014, p. 13).

The Škoda brand has built an image as the smart, rational choice for practical car buyers, focusing on high quality levels and functionality, with class-leading luggage space and a roomy interior all at an affordable price. "Simply Clever" means also that there are the clever little touches that make Škoda cars exceptional, such as an ice scraper behind the little door that covers the fuel tank cover, ticket holder or bag hooks for example. The objective of the Škoda growth strategy is to increase worldwide sales to at least 1.5 million vehicles per year (Škoda Auto, 2014).

But Škoda is not alone; it is a member of the VW family and should have to respect its position inside the group. "Škoda is definitely a challenger for the VW brand that must be taken seriously - that is simply the case," said a corporate consultant for the auto industry, who asked not to be named since VW is a client. "It's not just the products that are "simply clever". The people at Škoda think quicker and better than many of the people in Wolfsburg, who are too slow and traditional. Many of them could learn from Škoda" (Automotive News Europe, 2015).

"While former VW Group Chairman Ferdinand Piech encouraged internal competition as a motivational tactic to ensure no VW Group brand rested on its laurels, times are changing now that he has resigned. Škoda's string of success is attracting the wrong kind of attention at VW Group headquarters in Wolfsburg. Plans are now being forged to centralize more decisions in Germany - a move that could stifle Škoda's growth, analysts fear. The carmaker's high profits and fat margins contrast starkly with the ongoing problems with the much larger VW brand, which achieved a 2.5 percent return on sales last year - in part due to costs from developing the MQB (Modular Querbaukasten) architecture that is extensively used by Škoda" (Automotive News Europe, 2015).

To conclude, for the Czech Republic, Škoda Auto is crucial. It is the most successful Czech exporter. In the Czech TOP 100 ranking, Škoda Auto has been keeping the leading position since 1996, and in 2014, it was the most admired company in the Czech Republic. Škoda Auto is also one of the TOP 10 tax payers (in $20149^{\text {th }}$ place with 1.340 billion $\mathrm{CZK}$ ) and the $3^{\text {rd }}$ most demanded employer by Czech business school students, after Google and the Czech National Bank. 


\subsection{Japanese and French Manufacturers Joined Forces in TPCA Strategic Alliance}

In 2001, PSA (Peugeot Citroën) and Toyota signed a cooperation agreement concerning the joint development and production of small cars designed primarily for the European market, and embalmed by the Toyota, Peugeot and Citroën brands. The Toyota Peugeot Citroën Automobile Czech (TPCA) strategic alliance was established as a joint venture of Toyota Motor Corporation and PSA Peugeot Citroën. Cooperation of the two industrial giants allows use of the most advanced and efficient technologies in the automotive industry. "Toyota was in charge of development and production, while PSA Peugeot Citroën was responsible for purchasing. This project involves a total investment (research and development and industrial expenditure) of around $€ 1.5$ billion. Construction on the common plant started in 2002 and car production was launched in February 2005 at the TPCA plant in Ovčáry. The factory has a capacity of 300000 vehicles per year" (Junge, 2012, p. 37).

"We have combined the strengths and the synergies of the two companies ... with the strengths of the Czech Republic," says Javier Varela Sobrado, executive vice-president of the joint venture. "Competencies here are very high. In terms of suppliers and infrastructure, this is the most attractive place to build cars in Central Europe," he adds (Financial Times, 2014).

One of the main objectives of the TPCA strategic alliance is cost efficiency. TPCA is an example of the delocalization of production, and this project was used by the former French President Nicolas Sarcosy as an example of bad production in 2009. He said it was "not justifiable" for a French carmaker to outsource manufacturing of its French-sold cars to another European country.

TPCA expertise allows building three jointly designed compact city cars, which are almost identical in specifications, under the brands Peugeot 108, Citroën C1 and Toyota Aygo. "Thanks to a state of [the] art production line, all three models can be assembled at the same time, welded together by 200 robots" (Financial Times, 2014). Ninety-nine percent of production is exported. The TOP 5 export countries are France, Italy, Germany, the Netherlands and UK. TPCA is one of the most important employers in the region with 3000 employees, and $80 \%$ of components used at the TPCA are sourced from Czech suppliers (Financial Times, 2014).

But compared to Škoda Auto, TPCA has much lower value added for the country. The cooperation between PSA and Toyota ends at the door of the Czech factory. Marketing and sales are done by the two headquarters independently, outside of the Czech Republic, and Toyota and PSA are competing in the global market, the same as other brands. The concentration just on manufacturing and the lack of research and development centers in the country mean that TPCA amounts to little more than assemblers for the Czech Republic.

\subsection{Hyundai - The Largest Foreign Greenfield Investment in the Czech Republic}

The Hyundai project was the largest foreign greenfield investment in the history of the Czech Republic. The Hyundai Motor Company decided to extend its global manufacturing capacities by building a new plant in Europe. The company decided for the Czech Republic after long consideration of all alternatives and in very arduous competition with Poland, Hungary and Romania in 2006. The Hyundai Motor Manufacturing Czech 
(HMMC) is located in the Moravian-Silesian region, where the unemployment rate is one of the highest in the Czech Republic. Hyundai offered to create approximately 3300 jobs and an additional 7000 were created by component suppliers that followed Hyundai to the Czech Republic. The investment was huge; it amounted to $€ 1.22$ billion. These were the main reasons why the Czech government provided investment incentives worth some CZK 5 billion to Hyundai and its suppliers. The government and the Moravian-Silesian region spent another CZK 2 billion on preparations of the industrial zone. The region was to invest a total of CZK 10.5 billion in transport infrastructure that serves not only the car producers but was necessary for the regional development anyhow.

Launching car production in November 2008, the time of the global economic crises, seemed to be risky. Many other car manufacturers were cutting jobs and closing down plants in reaction to decreasing new car sales, especially in Europe. But Hyundai believed in its competitive advantage - the most modern European factory. For example, in the welding shop, there are only robots, and a huge welding machine is able to manufacture four different car models. At full operation, sixty cars leave the line every hour. To strengthen the positioning of a local car producer, the first three manufactured cars were white, red and blue - the colors of the Czech national flag.

In Nošovice, HMMC produces three models - ix20, ix35 and i30. The manufacturing facilities consist of a stamping shop, a welding shop, a paint shop, a final assembly shop and two transmission shops. The transmission shops are of particular importance as they produce transmissions not only for HMMC but also for the plant in Russia and for its sister company Kia Motors, based in Slovakia in Žilina, about $90 \mathrm{~km}$ from the Czech plant. Kia's Slovak plant is producing Cee'd Sportage and Venga brands and provides HMMC with motors. Thus, both factories are creating quite a unique entity of mutually cooperating units located in two neighboring countries.

In $2014,95.5 \%$ of production was exported to 55 countries. As the factory was built to serve European markets, more than $70 \%$ of manufactured cars were exported there, mainly in Germany, Russia, UK, Italy and Spain. "Since 2008, we have developed our business to become a truly 'European' brand. Our Czech plant is at the heart of our European success, producing the two best-selling Hyundai models in the region and making one car every minute. Its cars such as New ix35 and New Generation i30 that have helped us achieve a record-high European market share of 3.5\% in 2012," explains Allan Rushforth, former Senior Vice President and CEO, Hyundai Motor Europe (Czechinvest, 2015, p. 6).

HMCC is also targeting the local market and trying to compete with the dominant Škoda brand. Hyundai's market share is about $10 \%$ and the brand is number 2 or 3 on the market, depending on the sales success of its nearest competitor - the VW brands. Local marketing, based on "Made in Czech Republic" is very important for Hyundai's brand. For example, in 2014 - according to Nielsen Atmosphere - Huyndai invested CZK 496 million in advertising, much more than Škoda with CZK 379 million.

The influence of the South Korean company in the Czech Republic will grow consequently due to the decision of Hyundai to continue with a new $€ 96$ million greenfield investment. Hyundai Mobis will build a factory which will produce car lamps for Hyundai's manufacturing operations in the Czech Republic and Slovakia. It is scheduled to open in 2017 , and create around 900 jobs. 


\section{Conclusion}

The automotive industry is the pillar of the Czech economy. Czech Republic is the $13^{\text {th }}$ biggest world manufacturer, with 1246506 passengers cars produced in 2014. Three main global players decided to make huge investments in the small country, benefiting from the industrial tradition, skilled labor force and strategic location in the center of Europe. The German group Volkswagen participated in the privatization at the very beginning of the transition of the Czech economy. Brownfield investment, in the form of acquisition of a local state owned company, is a true success story for both the Czech economy and foreign investor. The decision of the development of the local brand, which became the fourth brand of the VW portfolio in 1991, gave a new breath of life to Škoda. Today, it is hard to imagine what would have become of the Czech Republic without Škoda Auto, the most successful Czech exporter, an important tax payer, employer of nearly 25000 people (1 600 employees of the local R\&D center included), and the most admired company in the Czech Republic in 2014. The "Simply Clever" strategy is so successful that the main threats for the company's growth is Škoda's position inside the VW group. The two cases of greenfield investment show the different strategic approaches. TPCA is an example of the delocalization of manufacturing with the main motivation of cost efficiency. The value added of this investment for the country is much lower than in the case of Škoda Auto. In between is Hyundai Motor Manufacturing Czech (HMMC) with its clear strategic long-term vision to build, in the Czech Republic, modern plants as the basis for its European growth. The factory is located in the Moravian-Silesian region, where the unemployment rate is one of the highest in the Czech Republic. Hyundai created not only 3000 jobs directly, but also an additional 7000 job positions were created by component suppliers that followed Hyundai to the Czech Republic, and the investment of Hyundai Mobis means the creation of another 900 new jobs. The geographical mix of German, French, Japanese and South Korean companies is quite unique and proves the capacity of the Czech industry to attract long-term strategic investors to the car passenger manufacturing sector.

\section{References}

Automotive News Europe (2015). Why Skoda's fast rise helps and hurts parent VW Group. Retrieved August 2, 2015 from: http://europe.autonews.com/article/20150706/ ANE/150629927/why-skodas-fast-rise-helps-and-hurts-parent-vw-group.

AutoSAP (2015). Basic Overview: Automobile Industry in the Czech Republic. Retrieved August 2, 2015 from: http://www.autosap.cz/zakladni-prehledy-a-udaje/

Canabal, A., \& White, G. O. (2008). Entry mode research: Past and future. International Business Review, 17(3), 267-284.

Coface (2015). Panorama overviews of Czech Republic, Coface, Niederlassung Austria, 2015. Retrieved July 31, 2015 from: http://www.coface.cz/content/download/106745/1669165/ file/Panorama+Czech+Republic.pdf

Czechinvest (2015). Automotive Industry in the Czech Republic, February 2015. Retrieved July 27 , 2015 from: http://www.czechinvest.org/data/files/automotive-brochure-2015-97-en.pdf

Financial Times (2014). Czech carmakers speed ahead but country faces competition. Retrieved July 30, 2015 from: www.ft.com/cms/s/0/2a5e5f94-2f87-11 e4-83e4-00144feabdc0. html\#axzz3iOYZ89vo. 
Guidote, B. (2008). A case study on the car industry of the Czech Republic, Tracing FDI trends in Central and Eastern Europe after 1990s. Core fields of European Culture III. 1990s. Retrieved May 24, 2015 from: http://www.euroculture.upol.cz/.

Junge, P. (2012). BWL für Ingenieure: Grundlagen-Fallbeispiele-Übungsaufgaben. Wiesbaden: Springer Science \& Business Media.

Keegan, W. J., \& Schlegelmilch, B. B. (2001). Global marketing management: A European perspective. Pearson Education.

Kornecki, L., \& Rhoades, D. (2007). How FDI facilitates the globalization process and stimulates economic growth in CEE. Journal of International Business Research, 6(1), 113.

Latorre, M. C. (2012). Industry restructuring in transition after the arrival of multinationals: a general equilibrium analysis with firm-type costs differences. Post-communist economies, 24(4), 441-463.

Latorre, M. C., \& Gómez-Plana, A. G. (2011). Multinationals in the Czech Motor Vehicles Industry: A General Equilibrium Analysis for a Transition Economy. Europe-Asia Studies, 63(8), 1425-1447.

Machková, H., Král, P., \& Lhotáková, M. (2010). International Marketing. Prague: Oeconomica Publishing House.

Machková, H., \& Mohelský, L. (2012). Is diversification as a Strategic Advantage? The Example of Automotive Components in the Czech Republic. Central European Business Review, $1(2), 37-45$.

OECD (2015). Glossary of statistical terms. Retrieved July 14, 2015 from: https://stats.oecd.org/ glossary/detail.asp?ID=1028

OICA (2014). Production statistics. Organisation Internationale des Constructeurs d'Automobiles. Retrieved July 14, 2015 from: http://www.oica.net/category/production-statistics/.

Škoda Auto (2014). Annual Report 2014. Retrieved July 18, 2015 from: http://www.tpca.cz.

Tyll, L. (2014). Podniková strategie (Corporate strategy). Prague: C. H. Beck.

Yin, R. K. (2014). Case Study Research: Design and methods. Thousand Oaks: Sage publications.

\section{Authors}

Prof. Ing. Hana Machková, CSc.

Rector

Faculty of International Relations

University of Economics, Prague

W. Churchill Sq. 4, 13067 Prague, Czech Republic

machkova@vse.cz

\section{Paul Marc Collin}

Lecturer

IAE Lyon

Université Jean Moulin Lyon 3

6 cours Albert Thomas

69355 Lyon, France

paul-marc.collin@univ-lyon3.fr 